\title{
Magyar nyelvü e-könyves adatbázisok az EISZ kínálatában
}

\begin{abstract}
Bevezetés
Az Elektronikus Információszolgáltatás Nemzeti Program (EISZ) 2001 óta végzi tudományos és közmüvelődési adatbázisok konzorciumi elöfizetését a magyar intézmények számára. A program adatbázis-portfóliója 2015 után rohamos bövülésnek indult, a korábbi években kialakult stabil, nagy létszámú konzorciumok mellett egyre több kisebb intézményi kört vonzó szakirodalmi adatbázis előfizetését vállalta magára a nemzeti program. ${ }^{1} \mathrm{~A}$ kisebb, nemzetközi szakirodalmi adatbázisokra létrejövő konzorciumok mellett a portfólió bővülésének másik eleme a magyar tartalmak jelentősebb mennyiségủ megjelenése az EISZ-ben.

A magyar nyelvű kínálat elsősorban e-könyves kiadói adatbázisok csatlakozásával növekszik, és a következő években további bővülés várható. A magyar e-könyves tartalmak megjelenése nem kizárólag a tudományos tartalomszolgáltatás számára jelent újabb forrásokat, az így hozzáférhető könyvek sok esetben kötelező irodalomként jelennek meg a felsőoktatásban, illetve közmüvelődési, tudománynépszerüsítő szerepük is jelentős. Szépirodalmi müvek - az EISZ küldetésének megfelelően - a bővülést követően sem szerepelnek a kínálatban.
\end{abstract}

\section{Magyar szolgáltatók az EISZ-ben}

\section{Az Akadémiai Kiadó adatbázisai}

Az Akadémiai Kiadó - mint a magyar tudomány nemzetközi viszonylatban legjelentősebb kiadója - a kezdetektől része az EISZ kínálatának. Szolgáltatásai között szerepel a kiadó válogatott folyóiratait kínáló adatbázis, illetve az egy- és többnyelvü szótárak gyüjteménye.

Az Akadémiai Kiadó Folyóiratai adatbázis évente változó számú angol és magyar nyelvü folyóiratot tartalmaz a kiadói portfólióból. 2018-ig állandó jellemzője volt, hogy az orvostudomány egyik legfontosabb magyar nyelvü folyóirata, az Orvosi Hetilap nem szerepelt a válogatásban. Ezzel együtt átfogó, multidiszciplináris adatbázisként és a magyar kutatói kör számára fontos publikációs fórumként - jelentős központi támogatás mellett - rendkívül széles intézményi

${ }^{1}$ Dér Ádám - Lencsés Ákos: Az EISZ Nemzeti Program szerepe a könyvtárak külföldi szakirodalommal való ellátásában. = Tudományos és Müszaki Tájékoztatás, 64. évf. 2017. 5. sz. 241-246. p. 
felhasználói kört vonz. A folyóiratok minden esetben tanulmányok szintjén, pdfformátumban hozzáférhetők.

2017-ben jelent meg a kiadó másik folyóirat-adatbázisa, az Akadémiai Kiadó Orvosi Folyóiratcsomag, amely az Orvosi Hetilapot is beleértve 3-4 kurrens folyóirathoz és 4-6 archív folyóirathoz biztosít hozzáférést. Az Orvosi Folyóiratcsomag 2019-ben megszünik, így az Akadémiai Kiadó Folyóiratai az orvosi címeket az általános folyóiratcsomagba integrálva egységes, a kiadó szinte valamennyi folyóiratához hozzáférést biztosító forrássá válik. A kibővített tartalom mellett ez megoldást kínálhat a korábbi évek egyik jelentős problémájára is: mivel a folyóiratok egy felületen szerepeltek, a felhasználók gyakran tanácstalanul álltak a jelenség előtt, hogy bizonyos címeket elérnek, bizonyos címeket pedig nem. Mivel az adatbázisok címlistája évről évre változott, ezért még a megszokott elérésekben is történhetett változás. Az új, kibővített folyóirat-adatbázisnál ez a jelenség már nem fordulhat elö.

Az Akadémiai Kiadó másik, régebb óta az EISZ kínálatában szereplő szolgáltatása az Akadémiai Kiadó Szótárai. Az adatbázisban több egy- és kétnyelvü szótár érhető el, de az egyes kötetek nem pdf-ként, hanem közös keresőben, szócikkenként xml-formátumban jeleníthetők meg. Ennek köszönhetően egyegy keresőkifejezés valamennyi szótár vonatkozó szócikkét listázza. A kétnyelvű szótáraknál az adatbázis folyamatos bővülésével az angol, francia, német nyelvü kiadványok mellett megjelentek a holland, az olasz, az orosz és a spanyol szótárak is.

A kiadó e-könyves adatbázisa 2016-ban jelent meg Magyar Elektronikus Referenciamüvek Szolgáltatás (MeRSZ) néven - az elnevezést később Magyar Elektronikus Referenciamü Szolgáltatásra módosították. Az első évben még csupán néhány tucat kötet volt elérhető a felületen, majd 2017-ben a kínálat rohamos bővülésnek indult, és a tervek szerint 2019-ben már 400 kötetet tartalmaz az adatbázis. A MeRSZ kimondott célja az egyetemi hallgatók elérése, illetve a kötelező irodalom online módon történő biztosítása. ${ }^{2}$ Ennek megfelelően az oldalon nemcsak szakterületi csoportosításban találhatók meg a kötetek, hanem egy-egy felsőoktatási intézmény kötelező irodalma szerint csoportosítva is. A felületen a kiadványok nem pdf-fájlként, hanem xml-formátumban, fejezetenként jelennek meg, biztosítva a jegyzetelés és a fejezetenkénti linkelés lehetőségét. Az adatbázis multidiszciplináris jellege mellett is megfigyelhető - a kiadói portfólióval egyezően - a közgazdaság-tudományi tartalmak túlsúlya. Ezt a tematikát

${ }^{2}$ Dér Ádám - Lencsés Ákos: Öszi információs napok az Akadémiai Könyvtárban. = Könyvtári Levelezö/lap, 28. évf. 2016. 1. sz. 7-14. p. 
tükrözik az adatbázis használati mutatói is: a Budapesti Corvinus Egyetem minden más intézményhez képest kiugró használatot tudhat a magáénak. ${ }^{3}$

\section{Az Arcanum Adatbázis Kft. által biztosított adatbázisok}

Az Arcanum Digitális Tudománytár (ADT), a magyar időszaki kiadványok legteljesebbnek mondható archív tartalomszolgáltatója 2016-ban jelent meg az EISZ-ben. Az adatbázisban nemcsak a magyar folyóirat-irodalom archív számai érhetők el, hanem hírlapok, közlönyök, hivatalos értesítők és más kiadványsorozatok is. Az adatbázisban a kiadványok szkennelt, karakterfelismert pdf-ként, oldalanként férhetők hozzá. Az ADT - mint a magyar bölcsészet- és társadalomtudomány egyik kiemelt forrása - a kezdetektől 100\% központi támogatásban részesül, ezért az EISZ tagintézményei további költségek nélkül férhetnek hozzá a szolgáltatáshoz. Nagyrészt az ADT-nek köszönhető, hogy az EISZ intézményi köre jelentősen növekedett az elmúlt években: múzeumok, levéltárak, közkönyvtárak, kutatóintézetek csatlakoztak a nemzeti programhoz. Összességében több mint 50 intézmény kizárólag az ADT hozzáférése miatt csatlakozott az EISZ-hez, 2018-ban több mint 170 intézmény alkotta az EISZ-es ADT-konzorciumot.

Az ADT-t üzemeltető Arcanum Adatbázis Kft. a folyóirat-adatbázisa mellett 2018-ban jelent meg a kifejezetten e-könyvek számára fejlesztett Szakkiadók Társulása (Szaktárs) felülettel. A Szaktárson a kiadók egy-egy aloldalon szerepelnek, ennek megfelelően az e-könyv-adatbázisokra kiadónként tudnak az intézmények elöfizetni. 2018-ban a felületen L'Harmattan Digitális Adatbázis néven érhető el a magyar nyelvü bölcsész- és társadalomtudományi területen meghatározó L'Harmattan Kiadó teljes portfóliója. A L’Harmattan jól példázza, hogy a magyar tartalmakra vonatkozó igény jelentős mértékü, és a nemzetközi adatbázisokhoz képest erösebben jelentkezik. A külföldi adatbázisok esetén a konzorcium megalakulása általában 4-6 intézmény részvételével történik, és a további években csatlakoznak újabb intézmények az elöfizetéshez. A L'Harmattan Digitális Adatbázis viszont már az első évben 47 előfizető intézményt vonzott. Így tulajdonképpen már a szolgáltatás megjelenésekor rendkívül stabil konzorciumot sikerült létrehozni.

A Szaktárs felületen 2019-től több kiadó kínálata válik elérhetővé: a bölcsészet- és társadalomtudományok területén kiemelt szereppel bíró Osiris Kiadó portfóliója, az elsősorban történettudományi és helytörténeti kiadványokat megjelentető Kronosz Kiadó, és az agrártudományi Szaktudás Kiadó. A későbbiekben a kínálat további kiadók köteteivel bővülhet. A Szaktárs az ADT technikai adottságait tükrözi: a kiadványok szkennelt, karakterfelismert pdf-ként oldalanként jelennek meg az adatbázisban. A felületen elérhető kiadói adatbázisok mind

${ }^{3}$ EISZ - Statisztika - 2018. első félév = http://eisz.mtak.hu/index.php/hu/statisztika/249statisztika-2018-1.html (2018. október 1.) 
külön szolgáltatásként értelmezendők: valamennyit egyesével lehet megrendelni. Ez segíti az intézményeket a számukra releváns tartalmak kiválogatásában, és nem kötelezi őket a Szaktárs valamennyi kiadói csomagjának előfizetésére.

\section{További magyar adatbázisok}

A Typotex Kiadó adatbázisa Typotex Interkönyv néven 2018-ban jelent meg az EISZ kínálatában. Az adatbázisban a kiadó műszaki, természettudományi, matematikai kötetei mellett kisebb mértékben társadalom- és bölcsészettudományi könyvek is elérhetők. Nem szerepelnek azonban az adatbázisban a kiadó szépirodalmi kötetei. Mivel a Typotex Kiadó évtizedek óta párhuzamosan jelenteti meg a nyomtatott és az e-könyveket, ezért a magyar szolgáltatók közül talán a Typotex számára volt a legkönnyebb az EISZ Nemzeti Program feltételrendszeréhez igazodni. Az egyes kötetek pdf-formátumban érhetők el, a felhasználók számára a könyvek 15\%-a nyomtatható, illetve elmenthető.

A Tinta Kiadó nyelvészeti kiadványokat és szótárakat jelentet meg, ${ }^{4}$ SzóTudásTár nevü adatbázisa 2018-ban jelent meg az EISZ kínálatában. Az adatbázisban 11 egynyelvü szótár kereshető közös felületen: értelmező szótár, etimológiai szótár, idegen szavak szótára, szinonima szótár, ellentétes jelentésű szavak szótára, régi szavak szótára, magyarító szótár, rövidítések szótára, kiejtési szótár, szólás- és közmondásszótár, összetételek szótára. Az egynyelvü szótárakat tartalmazó adatbázis hasznos lehet a nyelvészeti képzést nyújtó felsőoktatási intézményekben, ugyanakkor a szakkönyvtárak mellett kifejezetten fontos szolgáltatást jelenthet a közkönyvtárak, jelentősebb kézikönyv-állományt kezelő gyüjtemények esetén. Ezt az is alátámasztja, hogy az első évben előfizetö 13 intézmény többsége megyei könyvtár vagy szakkönyvtár volt, és csupán kettő egyetem.

\section{A magyar szolgáltatók megjelenése az EISZ-ben}

\section{Az online szolgáltatás feltételrendszere}

A magyar szolgáltatók számára sok esetben olyan követelményrendszert jelent az online világban való megjelenés, amelyre korábban nem voltak felkészülve. Mégis, valamennyi szereplő anyagi és emberi erőforrásokat egyaránt befektetett, hogy a nemzeti programban szereplő intézményi kör elvárásainak megfeleljen. Ilyen követelmények voltak az alábbiak:

- címlisták elkészítése az adatbázisokhoz,

- az egyes kiadványokhoz hivatkozható, állandó url rendelése,

- használati statisztika biztosítása intézményi szinten,

- távoli hozzáférés biztosítása a magyar eduID föderáción keresztül.

${ }^{4}$ A kiadó részletes bemutatását 1. Balázs Géza: A Tinta, az anya-nyelv-ész mühely. = Édes Anyanyelvünk, 39. évf. 2017. 3. sz. 13. p. 
Ezek mellett több esetben megvalósult az adminisztrátori felület fejlesztése is, amin keresztül ellenőrizhetők az intézményi beállítások, IP-címek, illetve önállóan lekérdezhetők egy-egy intézmény használati adatai.

Az EISZ Programtanács döntése értelmében 2019-ben az ADT továbbra is 100\% központi támogatásban részesül, a többi magyar adatbázis esetén az EISZ egységesen $25 \%$ támogatást biztosít az előfizető intézmények számára. ${ }^{5}$

Az újonnan megjelenő adatbázisok más munkamódszereket igényelnek az EISZ-nél korábban megszokott nemzetközi szakirodalmi adatbázisokhoz képest. A magyar e-könyvek felhasználói köre és célcsoportja a kutatók mellett leginkább egyetemi hallgatókból, közkönyvtári felhasználókból áll. Ennek megfelelően elsődleges fontosságú a magyar e-könyveket olyan módon hirdetni, hogy elérje a kívánt célcsoportot. Ennek legfontosabb megjelenési formája az online elérhetőség szerepeltetése a könyvtári katalógusokban és többforrású keresőkben (discovery service-ekben), az elérés megjelenése az online tanulmányi rendszerben és/vagy a kötelező irodalom jegyzékeiben. Valamennyi adatbázis esetén rendelkezésre áll olyan címlista, amely a könyveknél szerepelteti az állandó url-t. Mivel a hallgatók sok esetben nem a kutatók által használt forrásokat, keresőfelületeket veszik igénybe a kötelező irodalom eléréséhez, ezért kiemelten fontos az online elérhető e-könyvek megjelenése a könyvtári katalógusokban. Valamennyi magyar e-könyves adatbázisnál az előfizetés évében lehet hozzáférni a kiadványokhoz, és amennyiben az intézmény lemondja a szolgáltatást, a hozzáférés megszünik. A katalógus karbantartása ezért jelentős többletmunkát jelenthet, hiszen a lemondott adatbázisok linkjeit el kell onnan távolítani. Mégis elengedhetetlen, hogy az elöfizetett magyar tartalmak szerepeljenek a hallgatók, felhasználók által elsődlegesen igénybe vett információs forrásokban.

A hallgatók mellett fontos megismertetni az új szolgáltatásokkal az oktatói réteget is: nemcsak azért, hogy a kutatómunka során használni tudják a forrásokat, hanem azért is, hogy az oktató munkába integrálhassák azokat, és számonkérhessék a használatukat. A fix url-ek segítségével az előfizető intézményekben a kiadványok beépíthetők a kötelező irodalmak jegyzékeibe, a kurzusleírásba, szerepeltethetők az online tanulmányi rendszer erre alkalmas moduljában stb. Ez természetesen nem azt jelenti, hogy a hallgatóknak a későbbiekben nem kell elsajátítaniuk a könyvtári kereséseket vagy az adatbázisok használatát. Ez inkább egy új lehetőség a szolgáltatások bevezetésére: vonzóbbnak tűnhetnek a könyvtár szolgáltatásai, ha nem egyből a külföldi szakirodalom hozzáférése felől közelítjük meg, hanem a távoli hozzáférés segítségével a hallgatók számára otthonról is elérhető kötelező irodalmat tartalmazó adatbázisokat mutatjuk be számukra.

${ }^{5}$ EISZ - Információk - EISZ beszerzési terv 2019 = http://eisz.mtak.hu/images/PT dok/2018_06/koltsegvetes_2019_honlapra.pdf (2018. október 1.) 


\section{Távoli hozzáférés}

Az adatbázisok elsődlegesen IP-azonosítás alapján használhatók az előfizető intézmények IP-tartományához tartozó számítógépeken, illetve vezeték nélküli hálózatán. Emellett azonban valamennyi magyar adatbázis-szolgáltató csatlakozott a hazai eduID föderációhoz, melynek segítségével az intézmények hallgatói, oktatói, kutatói saját jelszó segítségével elérhetik ezeket az adatbázisokat az intézmény hálózatán kívül is. ${ }^{6} \mathrm{Az}$ egyes szolgáltatók emellett általában lehetőséget biztosítanak a VPN és Proxy kínálta távoli hozzáférésre is. Az Akadémiai Kiadó azon intézmények számára, amelyek nem tagjai az eduID föderációnak, távoli hozzáférést segítő egyéni kódokat ad ki, melyeket az intézmény saját hatáskörében oszthat ki a felhasználói számára.

Az egyes adatbázisok használati adatait vizsgálva jól látszik, hogy a hasonló típusú és méretü felsőoktatási intézmények, illetve megyei könyvtárak között is igen nagy a különbség a használat mértékében. ${ }^{7}$ Ennek természetesen nagyon sok magyarázata lehet, de biztosan szerepet játszik benne az új magyar nyelvü szolgáltatások népszerüsítése (illetve annak hiánya), az e-könyvek integrálása a katalógusba és más, a felhasználók által információkeresésre szánt oldalakba.

\section{Használati adatok}

A használati statisztika sok esetben nyújthat segítséget a könyvtárosok számára állománygyarapítási kérdésekben. A Typotex Interkönyv és a MeRSZ esetén intézményi bontásban is lekérdezhető egy-egy e-könyv használata, így leválogatható a leggyakrabban és a legkevésbé használt kiadványok listája. Ez nemcsak a beszerzések koordinálásában segíthet, hanem alacsony használat esetén azoknak a célcsoportoknak a beazonosításában is, amelyek még nem fedezték fel maguknak a tanulmányaik szempontjából releváns adatbázisokat.

A használati adatok vizsgálatánál nem szabad elfeledkezni arról, hogy az egyes adatbázisok lényegesen eltérő felületen és formátumban bocsátják rendelkezésre a kiadványokat. Ennek megfelelően csak rendkívül nagy körültekintéssel lehet öszszehasonlítani az adatbázisokat használati szempontból: nem lehet értelmezni egy oldalanként pdf-formátumban elérhető e-könyv használatát egy xml-formátumú vagy pdf-fájlként hozzáférhető kiadványhoz képest. A használati adatokat ezért csak egy adatbázison belül érdemes vizsgálni, összehasonlító adatokból nem lehet messzemenő következtetéseket levonni. A különböző formátumok miatt az e-könyv-használati statisztika még nemzetközi szinten is sok kérdést vet fel. ${ }^{8}$

${ }^{6}$ Az eduID-képes intézmények listáját 1 . Résztvevők - eduID = https://eduid.hu/hu/resztvevok (2018. október 1.)

${ }^{7}$ EISZ - Statisztika - 2018. első félév = http://eisz.mtak.hu/index.php/hu/statisztika/249statisztika-2018-1.html (2018. október 1.)

${ }^{8}$ Angela Conyers [et al.]: E-book Usage: Counting the Challenges and Opportunities. = Insights, 30 vol. 2017. 2. no. 23-30. p. https://doi.org/10.1629/uksg.370 


\section{Összefoglalás}

A magyar e-könyves adatbázisok megjelenése az EISZ Nemzeti Programban régóta igényelt szolgáltatások bevezetését teszi lehetővé a hazai könyvtári rendszerben. A magyar portfólió bővülésével a felsőoktatási könyvtárak és a közkönyvtárak egyaránt a felhasználói igényeknek megfelelő adatbázisokhoz biztosíthatnak hozzáférést.

Az adatbázisok megjelenése ugyanakkor új feladatokkal is jár a könyvtárosok számára: a célközönség elérése, az intézmény profiljának megfelelő adatbázisok kiválasztása, a használat elemzése, a szolgáltatások integrálása a könyvtári rendszerbe mind-mind olyan teendő, amely szükséges a szolgáltatás bevezetéséhez és fenntartásához. Ezek segítségével a magyar e-könyves adatbázisok és az azokat szolgáltató könyvtárak egyaránt betölthetik feladatukat a tudományos tartalomszolgáltatás, a felsőoktatás kötelező irodalommal való támogatása és a közkönyvtári tájékoztatás területén.

\section{Rezümé}

Az Elektronikus Információszolgáltatás Nemzeti Program (EISZ) több mint 50 adatbázishoz biztosít hozzáférést a magyar intézményhálózat számára. Magyar tartalmak kisebb mértékben már korábban is részét képezték az EISZ kínálatának, 2018-ban azonban már hét magyar adatbázis szerepelt a nemzeti program portfóliójában. A tanulmány bemutatja az EISZ-en keresztül elérhető magyar adatbázisokat, illetve tárgyalja, hogy milyen munkafolyamatok szükségesek ezeknek a tartalmaknak a könyvtári rendszerbe történő integrálásához.

\section{Hungarian e-book collections in the offer of EISZ}

The Electronic Information Service National Programme (EISZ) is the national consortium of Hungary. The consortium subscribes to more than 50 international databases each year, however Hungarian databases are a rather new phenomenon in the programme. In 2018 seven Hungarian databases are provided in the EISZ consortium for more than 200 institutions. The paper introduces the newly incorporated Hungarian databases, and focuses on the necessary workflow that helps to integrate these new resources into the library system.

LENCSÉS ÁKos

fökönyvtáros

MTA Könyvtár és Információs Központ EISZ Titkárság ORCID: 0000-0003-4461-1105 